\title{
Hypoksi eller hypoksemi?
}

\author{
Ordene hypoksi og hypoksemi oppfattes av mange som synonymer, men beskriver ulike prosesser. Den popu- \\ lære frasen «blodgass viste hypoksi» bør unngås, da en arteriell blodgassanalyse ikke med sikkerhet kan \\ avgjøre om en pasient er hypoksisk. Nedsatt partielt oksygentrykk $\left(\mathrm{PaO}_{2}\right)$ og/eller nedsatt oksygensaturasjon \\ $\left(\mathrm{SaO}_{2}\right)$ i arterielt blod skal omtales som hypoksemi.
}

Hypoksi refererer til en tilstand der cellene i ett eller flere organer ikke evner å opprettholde aerob metabolisme grunnet utilstrekkelig oksygentilgang. Dette er et resultat av nedsatt oksygenlevering og/eller manglende evne til å utnytte tilgjengelig oksygen. Resultatet av hypoksi er anaerob metabolisme med laktatproduksjon. Dersom prosessen ikke reverseres, vil hypoksi føre til progredierende organdysfunksjon.

Oksygenlevering til perifere vev $\left(\mathrm{DO}_{2}\right)$ er produktet av hjerteminuttvolum (cardiac output, $\mathrm{CO}$ ) og total oksygenkonsentrasjon $\mathrm{i}$ arterielt blod $\left(\mathrm{CaO}_{2}\right) \cdot \mathrm{CaO}_{2}$ avgjøres av hemoglobinkonsentrasjon ([Hb]), oksygensaturasjon av hemoglobinmolekylene $\left(\mathrm{SaO}_{2}\right)$ og partielt oksygentrykk $\left(\mathrm{PaO}_{2}\right)$ i arterielt blod (ramme 1). Siden hypoksi kan oppstå sekundært til nedsatt oksygenlevering, kan en reduksjon av en eller flere av disse faktorene potensielt føre til hypoksi dersom avviket ikke kompenseres tilstrekkelig (tab 1).

\section{Hypoksemi}

Hypoksemi betyr lavt oksygeninnhold i blod, og defineres oftest som nedsatt $\mathrm{PaO}_{2}(<9,6$ $\mathrm{kPa})$ og/eller nedsatt $\mathrm{SaO}_{2}(<95 \%)(1)$. Hypoksemi reflekterer nedsatt oksygenering over alveolær/kapillær-membranen i lungene, enten som resultat av lavt barometertrykk, hypoventilering, ventilasjon-perfusjonsdefekt og/eller diffusjonsdefekt. $\mathrm{PaO}_{2}$ og $\mathrm{SaO}_{2}$ reflekterer lungenes evne til å oksygenere blodet, men sier lite om hvorvidt perifere vev opprettholder aerob metabolisme.

Hypoksemi er en viktig årsak til hypoksi. Det er imidlertid viktig å være klar over at

\section{RAMME 1}

Formel for oksygenlevering til perifere vev

Oksygenlevering $\mathrm{DO}_{2}=\mathrm{CO} \times \| k_{1} \times[\mathrm{Hb}] \times$ $\left.\left.\mathrm{SaO}_{2}\right)+\left(k_{2} \times \mathrm{PaO}_{2}\right)\right)$

- $\mathrm{CO}=$ hjerteminuttvolum (cardiac output) $=$ pulsfrekvens $\times$ slagvolum

- $[\mathrm{Hb}]=$ hemoglobinkonsentrasjon i blod

- $\mathrm{SaO}_{2}=$ oksygensaturasjon $\mathrm{i}$ arterielt blod

- $\mathrm{PaO}_{2}=$ partielt oksygentrykk $\mathrm{i}$ arterielt blod

Tabell 1 Potensielle årsaker til vevshypoksi

$\begin{array}{lll}\text { Problem } & \text { Betegnelse/konsekvens } & \text { Ved manglende kompensering } \\ \text { Lav } \mathrm{CO} & \text { Sirkulasjonssvikt } & \text { Sirkulatorisk hypoksi } \\ \mathrm{Lav} \mathrm{Hb} & \text { Anemi } & \text { Anemisk hypoksi } \\ \mathrm{Lav} \mathrm{SaO}_{2} & \text { Hypoksemi } & \text { Hypoksemisk hypoksi } \\ \mathrm{Lav} \mathrm{PaO}_{2} & \text { Hypoksemi } & \text { Hypoksemisk hypoksi } \\ \text { Cyanidforgiftning, sepsis } & \text { Cellulær dysfunksjon } & \text { Histotoksisk hypoksi }\end{array}$

pasienter kan være uttalt hypoksemiske uten å være hypoksiske. Dette ses i situasjoner hvor kroppen kompenserer for hypoksemi gjennom en eller flere mekanismer, som økt $\mathrm{O}_{2}$-ekstraksjon fra blod, økt hjerteminuttvolum eller sekundær polycytemi.

Hypoksi kan også oppstå i fravær av hypoksemi. Eksempler på dette vil være situasjoner der perifert vev ikke klarer å utnytte tilgjengelig oksygen, slik som i cyanidforgiftning (som blokkerer oksidativ fosforylering) eller sepsis (hvor proinflammatoriske cytokiner og/eller bakterielle endotoksiner fører til mitokondriell dysfunksjon eller hemming av sentrale enzymer i aerob metabolisme) (2). Dette er blitt omtalt som histotoksisk hypoksi. Ved ren histotoksisk hypoksi vil tiltak for å øke $\mathrm{O}_{2}$-levering ikke resultere i økt vevsoksygenering (3).

Endeproduktet av glykolyse er pyruvat, som kan omdannes til henholdsvis acetyl CoA (via pyruvat dehydrogenase, $\mathrm{PDH}$ ) ved aerob metabolisme eller laktat (via laktat dehydrogenase) ved anaerob metabolisme. Siden laktat er endeproduktet $i$ anaerob metabolisme vil laktatstigning ofte reflektere vevshypoksi, men dette er ikke et spesifikt funn (4). Hos sepsispasienter har man observert nedregulering av $\mathrm{PDH}$, noe som forhindrer aerob metabolisme tross adekvat vevsoksygenering. I tillegg kan høy endogen adrenalinproduksjon hos sepsispasienter gjennom beta-2-reseptoragonisme føre til oppregulering av glykolyse med resulterende økning i pyruvatproduksjon. Dersom PDH ikke klarer å omdanne alle pyruvatmolekylene til acetyl CoA, vil overflødig pyruvat omdannes til laktat (2). I begge disse eksemplene ses altså laktatstigning i fravær av hypoksi.
Med dette ønsker vi å poengtere at hypoksi og hypoksemi refererer til to distinkte prosesser. Hypoksi er en organtruende tilstand, mens hypoksemi i mange tilfeller kompenseres uten organdysfunksjon. En arteriell blodgass kan identifisere risikofaktorer for hypoksi (anemi, hypoksemi) og gi mistanke om mulig pågående anaerob metabolisme (laktatstigning), men kan ikke med sikkerhet vurdere hvorvidt det foreligger vevshypoksi. Nedsatt $\mathrm{PaO}_{2} \mathrm{og} /$ eller $\mathrm{SaO}_{2}$ skal omtales som hypoksemi, og hypoksemiske pasienter er ikke nødvendigvis hypoksiske.

\section{Jens Vikse}

jensvikse@gmail.com

Børge Førland Gjøse

Jens Vikse (f. 1989) er turnuslege ved Medisinsk divisjon, Stavanger universitetssjukehus.

Børge Førland Gjøse (f. 1972) er seksjonsoverlege ved Infeksjonsmedisinsk seksjon, Stavanger universitetssjukehus.

\section{Litteratur}

1. Hypoksemi og hypoksi. I: Ordliste. Tidsskrift for Den norske legeforening. http://tidsskriftet no/ annet/ordliste (13.1.2017).

2. Garcia-Alvarez M, Marik P, Bellomo R. Sepsis-associated hyperlactatemia. Crit Care 2014: 18: 503.

3. McLellan SA, Walsh TS. Oxygen delivery and hemoglobin. Contin Educ Anaesth Crit Care Pain 2004; 4: 123-6.

4. Andersen LW, Mackenhauer J, Roberts JC et al. Etiology and therapeutic approach to elevated lactate levels. Mayo Clin Proc 2013: 88: 1127-40. 